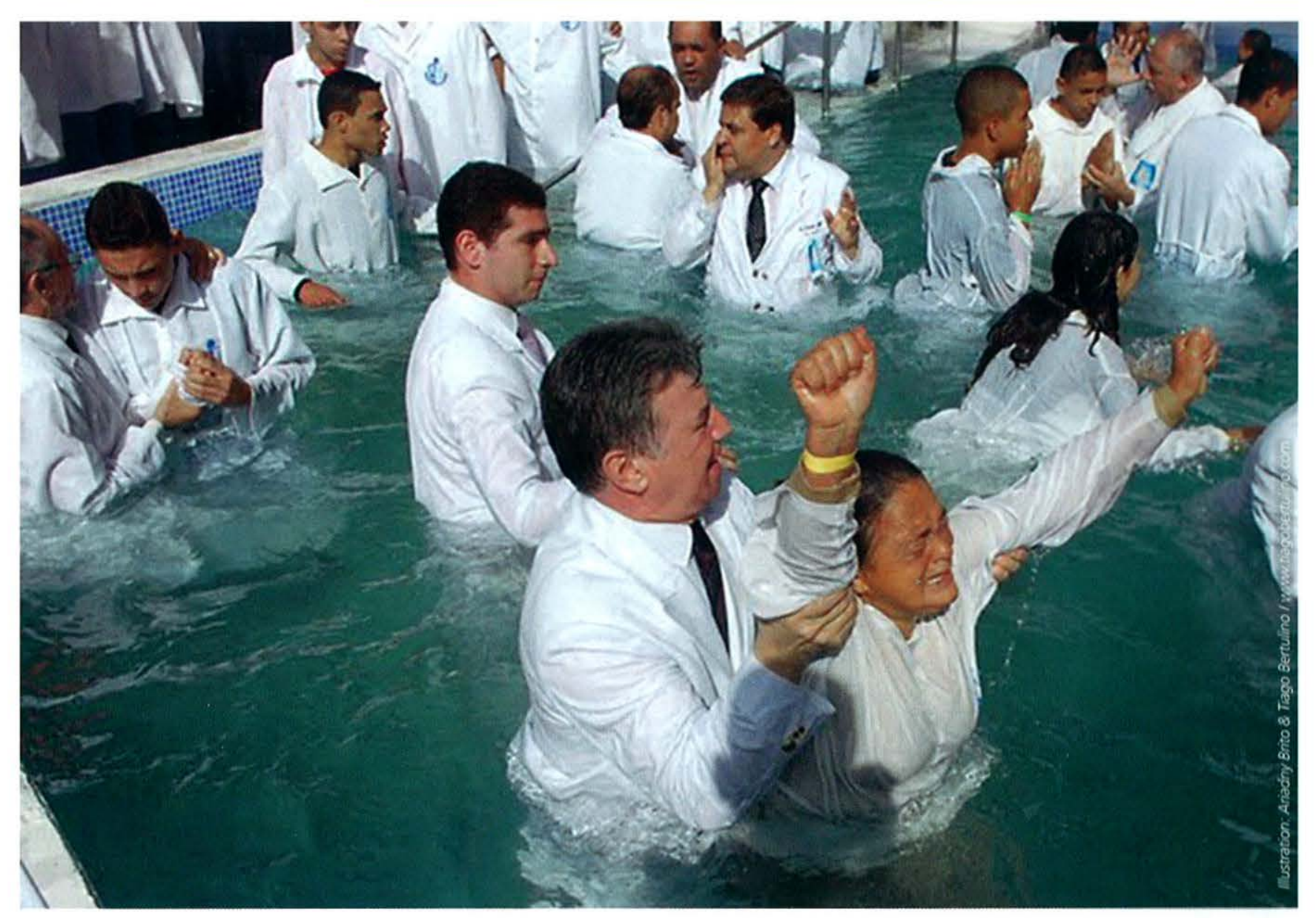

\section{Power, Powerlessness and the Holy Spirit}

In countries such as Guatemala and Nicaragua, a large proportion of the population belongs to the Pentecostal movement. Encounters with this faith community provide researchers with insights into a complex of religious practice, social inequality, and violence.

$\mathrm{B}$ rothers, we stand before the B reality of the agents of Satan God" with their extraordinary and supernatural powers. (...) And we are the agents of God, the Almighty! So I believe, brothers, we are at the beginning of a world-

$\begin{array}{ll}\text { wide conflict between the satanic } & \text { during the Guatemalan civil war. } \\ \text { powers and their agents and the } & \text { His words represent the growing indigenous Indian } \\ \text { farmer has a different story to tell: }\end{array}$

nuine power of the agents of

and organisations in political life. This warlike rhetoric, which They presuppose an envical life. might almost seem to be taken in which interpreting and coping from a Hezbollah radio broad- with life on the basis of religious cast, was delivered by an upper belief appears to be the only reamiddle-class Pentecostal preacher sonable choice.
"The soldiers dragged my brotherin-law out of his house durin the night. When he was found the next morning, he had been tortured and his throat had been cut. (...) Now the Bible itself says that when the end of the world is approaching, all these things will happen."

Both statements date from the time of the civil wars in Guatemala and Nicaragua and were recorded as part of a research project car as py the author in the mectried They point to chateric differences associated with the social status of the speakers.

The first, a professiona preacher, belongs to the uppe middle class, for whom war an economic crisis brought about crisis of their upward mobility. He swears himself and his fellow believers to a strategy of power and influence: We can bind all the powers of darkness ...! The second opts for a retreat into his congregation. This is the only security one has: to prepare oneself in order to be ready to meet the Lord. Both men belon to the Pentecostal movement that has spread rapidly in Latin Americ since the 1960s. Its members be lieve in the ecstatic experience the Holy Spirit of the Kingdo a whe coming quently emphasise God, and freof local churches.

However, sociological observation reveals that both men, who supposedly share the same Pentesupposedy theology, derive quite differentiglo political strategies from it.

Thirty years after my first research project in Guatema and Nicaragua, the marked polarisation of war-torn societies has given way to greater social Hosts" in the churches. For young y. Opportunities to participare in political life have significantly increased. The Pentecostal churches have also become more diverse. The wealth of Pentecostal symbolism, and the freedom with which its differen aspects may be combined produce very different variations of religious practice in different socia classes, age groups, and margin social groups.

countries, for instance, violence has changed its face. is no longer military, but crime is all-pervasive in civil society. A belief in the protection of the Holy Spirit creates a feeling of securit In many impoverished areas of the large cities, for example, one only two laws prevails: the arme law of the drug dealers on the streets or the law of the "Lord people, in particular, the Pentecostal churches often provide the only opportunity to escape the gangs, banish the "demons of violence" and to seek an alternative means of social integration.

The fight for social participation has also changed. The price of having a share in the aspirations of the emerging middle classes is extreme pressure - the threat of sliding down the ladder again in the event of the smallest slip in discipline. Services at middle in diss Pentecostal churches suply class Pentecostal churches supply an antidote to stress and burnout and special career coaching - all through the power of the Holy Spirit and of the Risen Christ. Religious shows at so-called megachurches respond to these expectations by driving out the "demons thes of the "Lord of ore" ondency" and

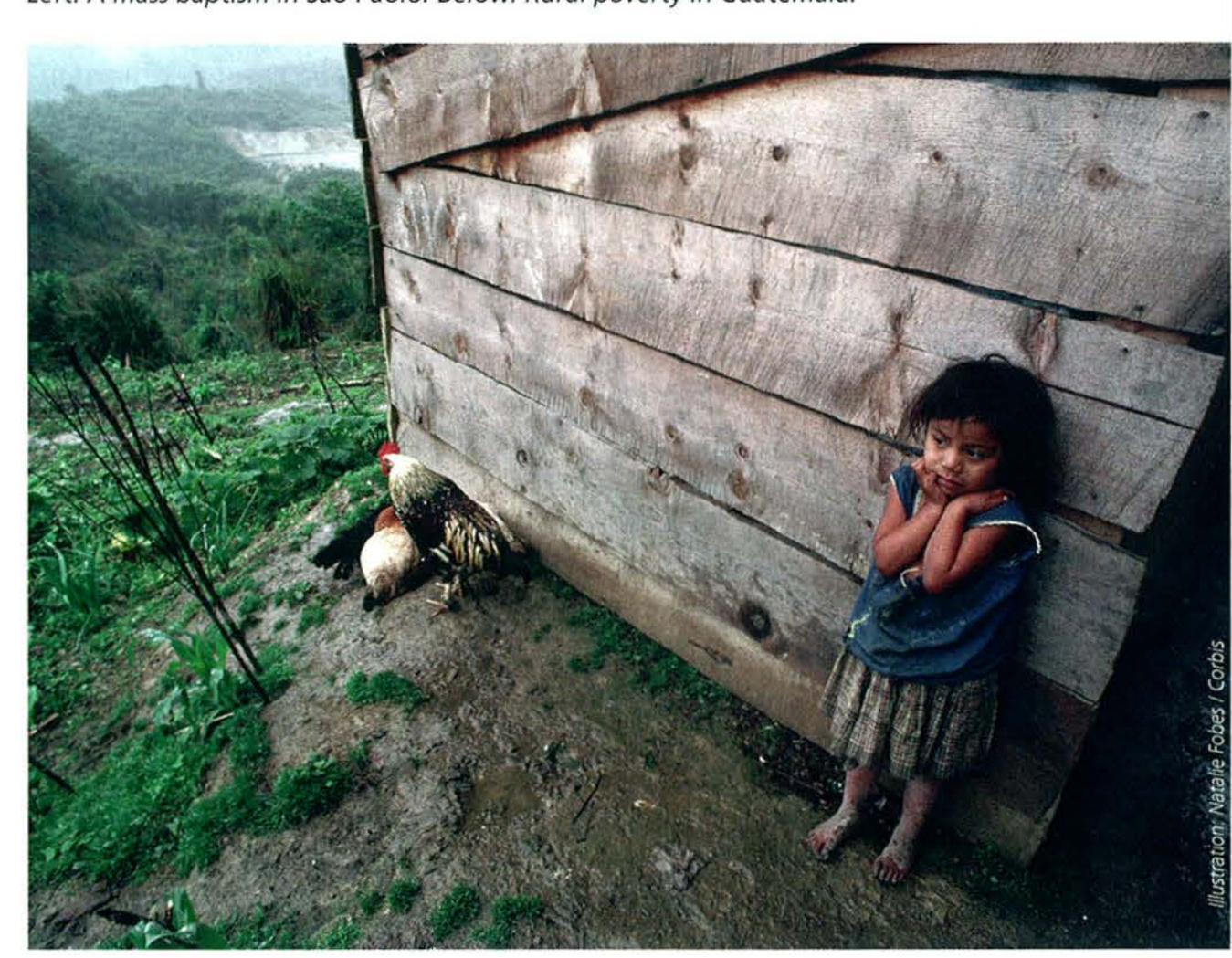


